TI 2014-155/VI

Tinbergen Institute Discussion Paper

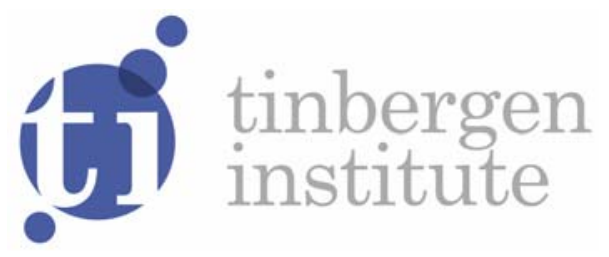

\title{
The Effectiveness of Dutch Municipal Recycling Policies
}

Elbert Dijkgraaf

Raymond Gradus ${ }^{2}$

' Erasmus School of Economics, Erasmus University Rotterdam, and Tinbergen Institute, the Netherlands;

2 Faculty of Economics and Business Administration, VU University Amsterdam, the Netherlands. 
Tinbergen Institute is the graduate school and research institute in economics of Erasmus University Rotterdam, the University of Amsterdam and VU University Amsterdam.

More TI discussion papers can be downloaded at http://www.tinbergen.nl

Tinbergen Institute has two locations:

Tinbergen Institute Amsterdam

Gustav Mahlerplein 117

1082 MS Amsterdam

The Netherlands

Tel.: +31(0)205251600

Tinbergen Institute Rotterdam

Burg. Oudlaan 50

3062 PA Rotterdam

The Netherlands

Tel.: +31(0)10 4088900

Fax: $+31(0) 104089031$

Duisenberg school of finance is a collaboration of the Dutch financial sector and universities, with the ambition to support innovative research and offer top quality academic education in core areas of finance.

DSF research papers can be downloaded at: http://www.dsf.nl/

Duisenberg school of finance

Gustav Mahlerplein 117

1082 MS Amsterdam

The Netherlands

Tel.: +31(0)20 5258579 


\title{
The effectiveness of Dutch municipal recycling policies
}

\author{
Elbert Dijkgraaf ${ }^{1}$, Raymond Gradus $^{2}$
}

\section{Abstract}

The EU advocates a household waste recycling rate of more than $70 \%$. Although the Netherlands already years ago invested in recycling policies heavily, this is still a large challenge as nowadays on average this rate is approximately $50 \%$ and nearly no municipalities have a rate above $70 \%$. Given the experience, it is possible to learn from the Dutch experience which policies are effective in increasing the recycling rates. Based on a large panel data set for the Netherlands, we show that unit-based pricing, avoiding a duo-bin for unsorted and compostable waste, and moving back the frequency of collecting unsorted and compostable waste at the curbside are effective in raising the recycling rate. However, only unit-based pricing has a substantial effect. In nearly all cases changing the frequency of collection of recyclables had no or very small effects. We find some evidence for the effectiveness of adding bring locations to curbside collection. Based on an estimation of the cost function most policies have no effect on costs, except for unit-based pricing (saving on cost) and increases in the frequency of unsorted waste collection (cost increasing). Overall, it seems nearly impossible to reach the EU-goal of $70 \%$ with the policies applied.

JEL classification: Q18, Q38, R11, R15.

Keywords: recycling; waste policy; recycling; local government; Netherlands.

\footnotetext{
${ }^{1}$ Erasmus School of Economics and Tinbergen Institute, Erasmus University Rotterdam, email: dijkgraaf@ese.eur.nl

${ }^{2}$ Faculty of Economics and Business Administration, VU University Amsterdam, email: r.h.j.m.gradus@vu.nl
} 


\section{Introduction}

Lack of space and a growing environmental awareness forced Dutch governments to take measures early on in the 1980s and 1990s to reduce the landfilling of unsorted (household) waste and to stimulate recycling. Later on, these measures were intensified with a tax on landfilling, a landfill ban (see Dijkgraaf 2004) and very recently an incineration tax. Dutch municipalities are responsible for waste collection and they applied policies to stimulate the separation of waste. On average Dutch municipalities recycle 50\% in the period 1998-2012, which is still below the EU-target of $70 \%$ as proposed by the European Commission (see Euroactiv (2014)). By law, Dutch municipalities are obliged to collect two types of waste at the curbside: compostable waste such as vegetable, food and garden waste and unsorted (household) waste. Since January 1994, compostable waste has been collected at the curbside. This was an important measure in increasing the separately collected amount of compostable waste. Furthermore, the municipalities are since 1994 obliged to provide an infrastructure for the separate collection of glass, paper and textile. They are not obliged, however, to collect these streams at the curbside.

Dijkgraaf and Gradus (2014b) show that there has been an increase in facilities at drop-off centers for collecting different waste streams such as paper, glass, textiles and also plastic packaging. This is a result of the municipal obligation to collect separately paper, glass, textiles and since recently also plastic packaging. Nevertheless, municipalities may choose how these materials are collected. Therefore, in some cases they are not collected at the curbside, but citizens can deliver them to collection points at central locations. In the literature there is discussion which method (curbside collection or drop- off centers) is most effective in collecting recyclables. For US municipal data, Beatty et al. (2007) show that the marginal impact of expanding curbside collection on recycled quantities is small, because curbside programs 'cannibalize' returns from drop-off centers. In fact, for aluminum and glass they cannot reject the null hypothesis of no relationship between increased curbside access and the quantity recycled. However, for plastics they found a significant relation between the percentage of population served by curbside programs and the amount of recycled plastics.

Several Dutch municipalities introduced unit- based pricing of unsorted and compostable waste as a measure to stimulate the separate collection of recyclables and to stimulate reducing the total amount of waste as well. In the last ten years, more and more Dutch municipalities have implemented unit-based user fees. By 2012,36\% of Dutch municipalities 
had implemented such a system, while in 1998 this was only $15 \%$. Based on 1998-2000 Dutch municipal data, Dijkgraaf and Gradus (2004) find sizeable and significant effects resulting in less unsorted and more recyclable waste. Based on data until 2005-06 and corrected for environmental activism or municipal fixed effects, the effects of unit-based pricing (UBP) systems still remain large (see Dijkgraaf and Gradus (2009) and Allers and Hoeben (2010)). For the period 1998-2010 a similar picture occurs, although there is some evidence that especially the effectiveness of the complex weight-based pricing system deteriorates over time (see Dijkgraaf and Gradus (2014b)).

In UK studies such information is not available as local government in the UK are not allowed to charge for waste collection (see Abbott et al. (2011, p. 2215)). As far as we known, research on how the effects of collection frequency and the unit-based pricing systems compare to each other does is limited. An important exception is Kinnaman and Fullerton (2000), who draws on US municipal survey data and investigates a garbage fee and curbside recycling program simultaneously. They show that the effect of a garbage fee on recycling is somewhat higher than those usually found in the literature, but it was insignificant. For a curbside recycling program they found that the (yearly) quantity of recycled materials increased with (almost) 200 US-pounds. ${ }^{3}$ However, their estimation is based on survey 1991data and it would be interesting to analyze recent panel data as this curbside recycling programs have developed over time. Moreover, panel data make it possible to include a fixed effect at the municipal level, which is important to understand the real effect of policy measures as it corrects of unobserved heterogeneity between municipalities (see for example Dijkgraaf and Gradus (2014a, 2014b)).

Moreover, other authors claim that a key non-monetary initiative is the provision of a frequent curbside recycling services (see for example Callan and Thomas (1997, 2001), Kinnaman and Fullerton (2000), Ferrera and Missios (2005), Kipperberg (2007) and Usui (2008)). More recently, based on UK municipal panel data Abbott et al. (2011) study the determinants of dry recycling and composting rates separately. They suggest that it is helpful by explaining the variation in the total recycling rate to disaggregate in dry and composting recycling. For composting a complex pattern of its own frequency of collection, the residual waste collection frequency and the type of container is important. In addition, they show that there is evidence

\footnotetext{
${ }^{3}$ One US pound is defined as 453 grams.
} 
that a lower collection frequency of residual waste increases dry recycling rates. This is interesting as some Dutch policy advisers in the Netherlands suggest moving back the residual waste collections frequency could encourage recycling as well (see Reus and Jonkergouw (2013)).

For the Netherlands until now no attention is given to the effectiveness of curbside collection of recyclables. This was due to a lack of data. In this contribution we fill this gap in the literature, based on a large panel data set (1998-2012) for the Netherlands with information on local waste policies. Moreover, we add to the literature by being able to distinguish the effect of curbside collection and type of container between unsorted, compostable, paper, glass, textile and plastic waste. Furthermore, we analyze whether combining drop-offs centers with curbside collection and whether type of curbside container (mini-bin, duo-bin for two different waste types ${ }^{4}$, bag or crate) influences the results. Finally, we are able to include fixed effects as we have a large panel.

In the literature not only the effect of curbside collection on recycling rates plays an important role, but also the effects on the cost of waste collection. In Dijkgraaf and Gradus (2014a) we show that the effects of institutional modes (public, private, in-house) on costs are small and very often not significant. However, the cost effects for unit-based pricing differ per system and are sometimes large. Interestingly, based on cost reduction the bag-based and frequencybased systems are preferred to the weight-based system (see Dijkgraaf and Gradus (2014a)). In this contribution we add the frequency of curbside collection and type of container to the cost function to test their influence on costs. If costs increase with a more frequent collection of unsorted waste this could be an additional argument for moving back the residual waste collections frequency.

The paper is organized as follows. In section 2, data and method are discussed. In section 3, estimation results for the recycling rates are given. In section 4, we give estimations for the cost function. Finally, section 5 contains some conclusions.

\footnotetext{
${ }^{4}$ This duo-bin is in many occasions simultaneously used for unsorted waste and compostable waste.
} 


\section{Method and data}

Similar to Abbott et al. $(2011)^{5}$, we model the local authority recycling rate as a function of socio-economic variables, unit-based pricing dummies, curbside frequency variables and dummies for nearby collection points as follows:

$$
\begin{aligned}
& R R_{i k t}=\alpha_{0}+\beta_{1} \ln (H Z)_{i t}+\beta_{2} \ln (P D)_{i t}+\beta_{3} \ln (F O)_{i t}+\beta_{4} \ln (Y)_{i t}+\sum_{j=1}^{n} \gamma_{j} U B P_{j i t}+ \\
& \sum_{k=1}^{m} \theta_{k} F R_{k i t}+\sum_{k=1}^{m^{\prime}} \delta_{k} B R_{k i t}+\sum_{\substack{1 \leq k \leq m \\
1 \leq s \leq d}} \emptyset(k, s) C R_{s k i t}+\alpha_{0}+\varepsilon_{i t},
\end{aligned}
$$

where $R_{\mathrm{ikt}}$ is the recycling rate of municipality $\mathrm{i}$ of material $\mathrm{k}$ at time period $\mathrm{t}, \ln (\mathrm{HZ})$ is the $\log$ of average household size, $\ln (\mathrm{PD})$ is the $\log$ of population density, $\ln (\mathrm{FO})$ is the $\log$ of the non-western foreigners share and $\ln (\mathrm{Y})$ us the log of income per inhabitant, $\mathrm{UBP}_{\mathrm{s}}$ are dummies with the value 1 for municipalities that use a unit-based pricing system of type $\mathrm{j}$ (volume, frequency, bags and weight), $\mathrm{FR}_{\mathrm{k}}$ is a variable that denotes for the $\mathrm{k}$-th material the number of times in a year curbside collection takes place and $\mathrm{BR}_{\mathrm{j}}$ is a dummy variable with value 1 if for the $\mathrm{k}$-th material there are central drop-off locations as well as curbside collection and $\mathrm{CR}_{\text {skit, }}$ a dummy for container-type s (mini-bin, duo-bin, bag or crate with the mini-bin as benchmark). Finally, $\alpha_{\mathrm{i}}$ are municipal fixed effects and $\varepsilon_{\mathrm{i}, \mathrm{t}}$ is the normally distributed error-term. ${ }^{6}$

Data on unit-based pricing and the amount of waste and recyclables come from Agentschap $N L$. We have data for 519 municipalities for the period 1998-2012, with a total of 5,321 observations. ${ }^{7}$ In addition, cost data on waste collection come from Agentschap NL as well. We have cost data for this period with a total of 6300 observations. Furthermore, Statistics Netherlands (CBS) also collects yearly information on the number of times in a year curbside collection of (unsorted) waste takes place and whether there are other facilities in a

\footnotetext{
${ }^{5}$ Abbott et al. (2011) argue that the theoretical literature does not suggest a particular functional form for the relationship between recycling and independent variables. Therefore, recycling performance can enter the model in a variety of ways: volume; participation rate in curbside scheme; or recycling rate. Similar to Abbott et al. (2011), we choose the latter since most policymakers evaluate the effectiveness of recycling and waste management programmes by considering the recycling rate.

${ }^{6}$ In this case, it will be assumed that the standard errors for each municipality are not independently and identically distributed, that there is unknown correlation in $\varepsilon_{i, t}$ between municipalities in group i within $t$, but that groups $\mathrm{i}$ and $\mathrm{j}$ do not have correlated errors (see Nichols and Schaffer (2007)).

${ }^{7}$ The number of Dutch municipalities decreased from 548 in 1998 to 415 in 2012. For 1998, data are available on $72 \%$ of the municipalities. From 2001, data on almost all municipalities (more than 95\%) are available. For some small merged municipalities, data are only available in a couple of years.
} 
Table 1. Descriptive statistics

\begin{tabular}{|c|c|c|c|c|c|}
\hline & Average & St.dev. & Max. & Min. & Obs. \\
\hline Unsorted waste as $\%$ total collected waste & 0.50 & 0.10 & 0.90 & 0.10 & 5321 \\
\hline Compostable waste as $\%$ total collected waste & 0.25 & 0.08 & 0.55 & 0.00 & 5321 \\
\hline Paper waste as $\%$ total collected waste & 0.18 & 0.05 & 0.47 & 0.00 & 5321 \\
\hline Glass waste as $\%$ total collected waste & 0.05 & 0.02 & 0.20 & 0.00 & 5321 \\
\hline Textile waste as $\%$ total collected waste & 0.01 & 0.01 & 0.08 & 0.00 & 5321 \\
\hline Plastic waste as $\%$ total collected waste & 0.02 & 0.02 & 0.14 & 0.00 & 1972 \\
\hline Costs municipality (mln euro) & 3.55 & 7.38 & 131.66 & 0.10 & 6300 \\
\hline Household size & 2.48 & 0.20 & 3.65 & 1.68 & 5321 \\
\hline Population density & 0.01 & 0.01 & 0.37 & 0.00 & 5321 \\
\hline Foreigners/inhabitant & 0.05 & 0.04 & 0.37 & 0.00 & 5321 \\
\hline Income/inhabitant (thousand euro) & 30.55 & 4.14 & 54.87 & 5.08 & 5321 \\
\hline UBP: Volume & 0.07 & 0.26 & 1 & 0 & 5321 \\
\hline UBP: Frequency & 0.13 & 0.33 & 1 & 0 & 5321 \\
\hline UPB: Bag & 0.04 & 0.20 & 1 & 0 & 5321 \\
\hline UBP: Weight & 0.05 & 0.21 & 1 & 0 & 5321 \\
\hline Bring: Paper & 0.41 & 0.49 & 1 & 0 & 5321 \\
\hline Bring: Glass & 0.07 & 0.25 & 1 & 0 & 5321 \\
\hline Bring: Textile & 0.67 & 0.47 & 1 & 0 & 5321 \\
\hline Frequency: Unsorted & 30.41 & 10.19 & 52 & 4 & 1972 \\
\hline Frequency: Compost & 29.79 & 10.89 & 52 & 0 & 5321 \\
\hline Frequency: Paper & 14.91 & 11.21 & 52 & 0 & 5321 \\
\hline Frequency: Glass & 2.17 & 8.63 & 52 & 0 & 5321 \\
\hline Frequency: Textile & 5.70 & 9.24 & 52 & 0 & 5321 \\
\hline Frequency: Plastic & 6.60 & 10.19 & 52 & 0 & 1972 \\
\hline Unsorted: duo-bin & 0.09 & 0.29 & 1 & 0 & 1972 \\
\hline Unsorted: mini-bin & 0.85 & 0.35 & 1 & 0 & 1972 \\
\hline Unsorted: bag & 0.12 & 0.32 & 1 & 0 & 1972 \\
\hline Compostable: duo-bin & 0.09 & 0.29 & 1 & 0 & 1972 \\
\hline Compostable: mini-bin & 0.90 & 0.30 & 1 & 0 & 1972 \\
\hline Compostable: bag & 0.02 & 0.14 & 1 & 0 & 1972 \\
\hline Compostable: crate & 0.01 & 0.10 & 1 & 0 & 1972 \\
\hline Paper: duo-bin & 0.01 & 0.08 & 1 & 0 & 1972 \\
\hline Paper: mini-bin & 0.35 & 0.48 & 1 & 0 & 1972 \\
\hline Paper: bag & 0.03 & 0.16 & 1 & 0 & 1972 \\
\hline Paper: crate & 0.59 & 0.49 & 1 & 0 & 1972 \\
\hline Glass: duo-bin & 0.00 & 0.02 & 1 & 0 & 1972 \\
\hline Glass: mini-bin & 0.01 & 0.08 & 1 & 0 & 1972 \\
\hline Glass: crate & 0.04 & 0.20 & 1 & 0 & 1972 \\
\hline Textile: duo-bin & 0.00 & 0.02 & 1 & 0 & 1972 \\
\hline Textile: mini-bin & 0.05 & 0.21 & 1 & 0 & 1972 \\
\hline Textile: bag & 0.56 & 0.50 & 1 & 0 & 1972 \\
\hline Textile: crate & 0.10 & 0.30 & 1 & 0 & 1972 \\
\hline Plastic: duo-bin & 0.00 & 0.07 & 1 & 0 & 1972 \\
\hline Plastic: mini-bin & 0.05 & 0.21 & 1 & 0 & 1972 \\
\hline Plastic: bag & 0.30 & 0.46 & 1 & 0 & 1972 \\
\hline Plastic: crate & 0.03 & 0.16 & 1 & 0 & 1972 \\
\hline
\end{tabular}

Note: Unsorted waste is not collected with crates and glass is not collected in bags. 
municipality. ${ }^{8}$ That information is not available publicly and has been sent to us upon request in July 2014. Data for the socio-economic characteristics come from CBS as well and they are available publicly. For descriptive statistics, see Table 1 (see Appendix A for the variable definitions).

For 1998-2012, the (recycling) rate is constructed separately for unsorted waste, glass, textile, paper and compostable waste. As we have only data for plastics from 2007 on, the plastic recycling rate is only constructed for 2007-2012. The same subsample is used for the container type variable as data before 2007 are not available.

Figure 1. Recycling rates as \% total waste 1998-2012

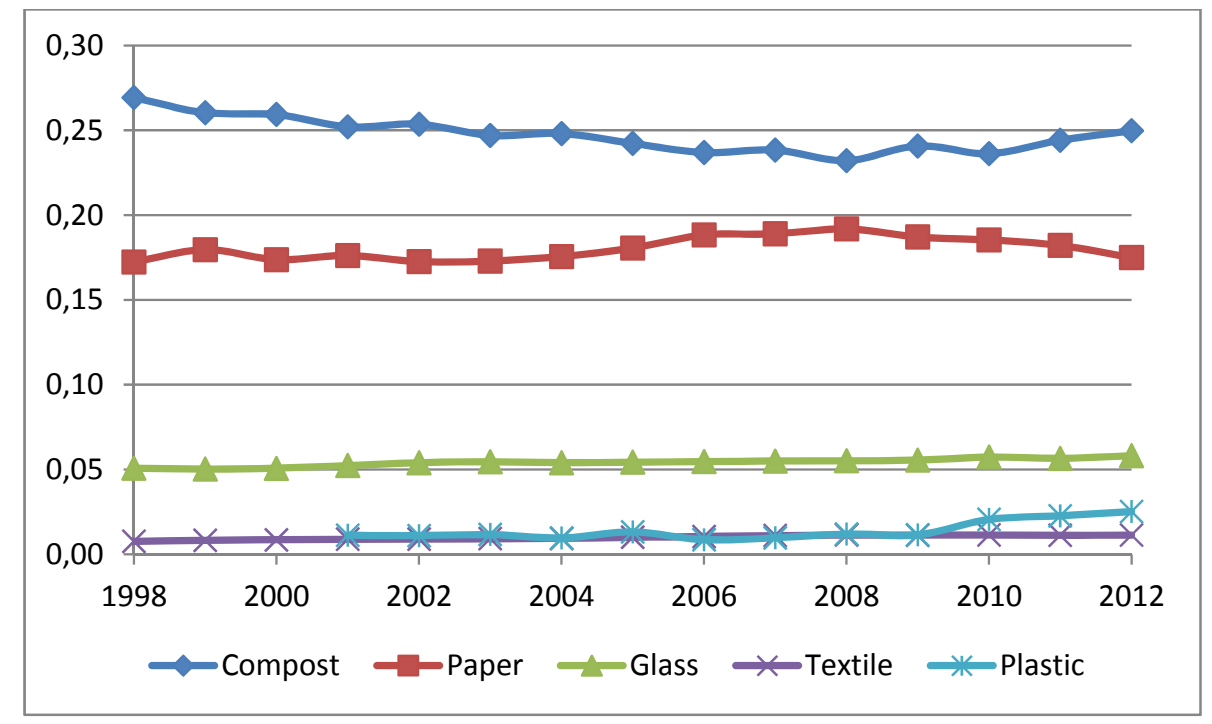

While the Dutch's recycling rate is more or less stable in time with the exception of plastic at the end of the period (Figure 1), it is noticeable that there are significant variations between municipalities. In Figure 2 we present the share of recycled waste in total waste and the number of municipalities, which recycle more in 1998 and 2012.

Figure 2 shows that there are some municipalities which recycle more than $70 \%$ and there are a few municipalities which recycle less than $30 \% .{ }^{9}$ On average, Dutch municipalities recycled

\footnotetext{
${ }^{8}$ It should be noticed that in 2007 this VRAGENLIJST GEMEENTELIJK AFVAL has been changed dramatically and therefore some variables are only available from 2007 on.

${ }^{9}$ Due to mergers the number of municipalities between 1998 and 2012 decreased. In 1998 the number of municipalities with a recycling rate less than $70 \%$ was $383(98 \%)$ and in 2012 it was $328(95 \%)$.
} 
$50 \%$ of their waste in 1998 and $48 \%$ in 2012 . However, the number of municipalities with a recycling rate more than $70 \%$ is still small, although it doubled from 8 to 16 .

\section{Figure 2. Recycled waste as share of total waste}

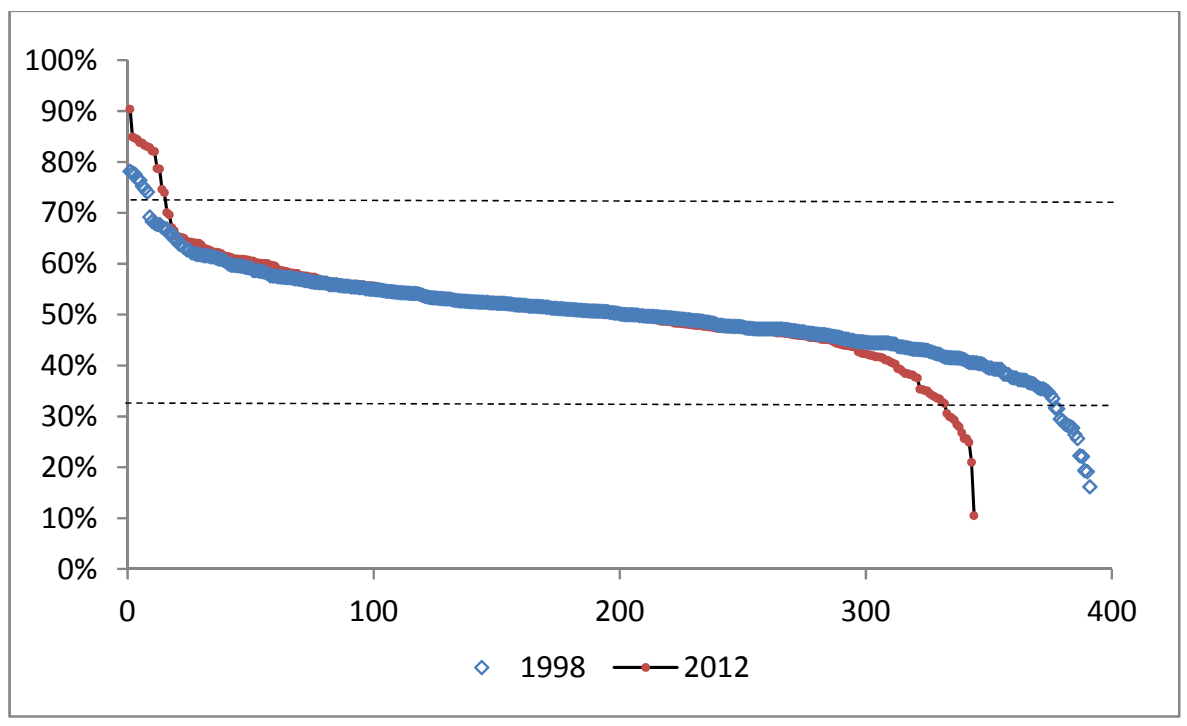

Dutch municipalities may choose how materials as paper, glass, textile and plastics are collected. If they are not collected at the curbside, citizens can deliver them to collection points at central locations nearby as shopping centers or schools. Unsorted waste is collected at the curbside in all municipalities. For paper this is $89 \%$. For textile this is $77 \%$ and for plastics this is $40 \% .^{10}$ There is a large difference between the frequency of collecting unsorted and compostable waste versus different recyclables (see Figure 3). In addition, most municipalities collect unsorted and compostable waste every two weeks. For compostable waste, $74 \%$ of the municipalities collect it every two weeks, while $15 \%$ collect it every week. These figures are $80 \%$ and $18 \%$ for unsorted waste. Most municipalities collect paper once each month (or every four weeks). For paper, $63 \%$ of the municipalities collect one time a month (11-14 times a year), while 14\% collect two times a month (24-27 times a year) and $5 \%$ collect each week. Glass and textile are collected at the curbside to a lesser extent. Of all municipalities $77 \%$ collect textile and $7 \%$ collect glass at the curbside. However, for textile $48 \%$ of municipalities collect it every quarter. Plastics are collected at the curbside in $40 \%$ of the municipalities. Half of these municipalities collect it once a month and $9 \%$ twice a month.

\footnotetext{
${ }^{10}$ For compostable waste curbside collection is $94 \%$. It should be noticed that for compostable waste, although curbside collection is obliged by law, some municipalities get exemptions to collect compostable waste for large parts of their city as they are many flats (e.g. Amsterdam).
} 
Figure 3. The curbside frequency, all municipalities, 1998-2012

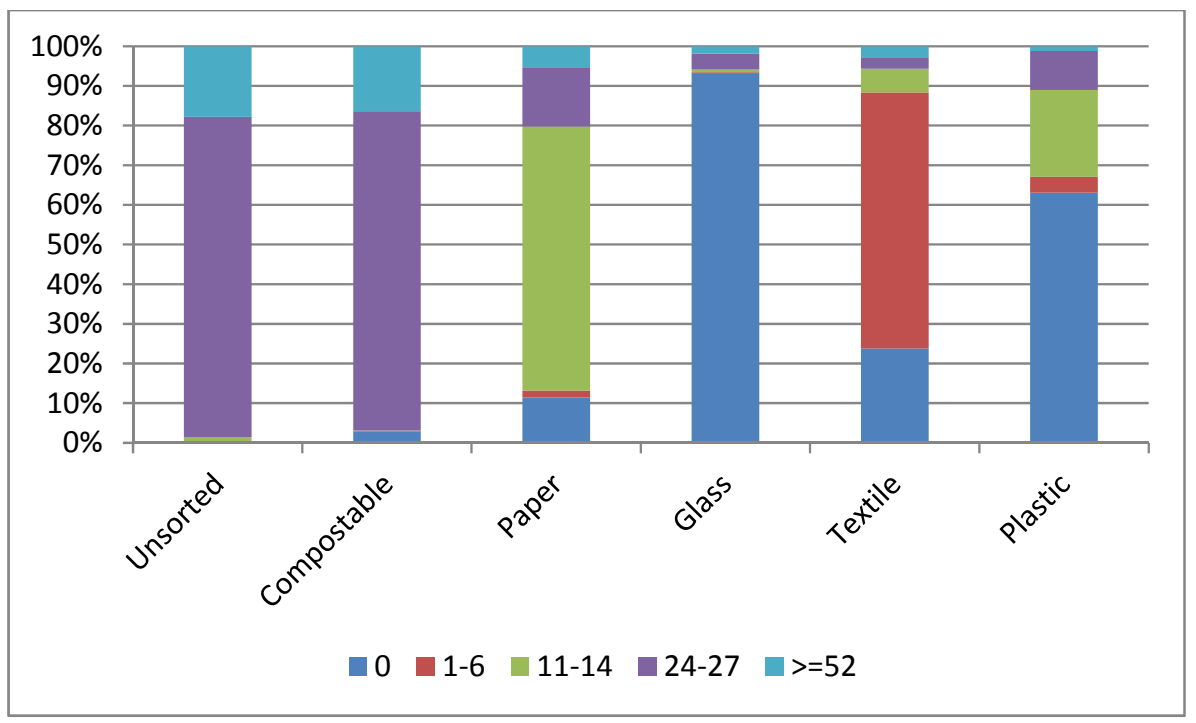

Figure 4 shows the number of pickups at the curbside on average for all municipalities. It shows that for most waste streams the frequency declines over time. The exceptions are the first few years for compostable waste, paper and textile and the last few years for plastic.

The type of container differs considerable between different materials. For unsorted waste most municipalities collect it by a mini-bin of 120 or 240 liter $(85 \%)$. Other municipalities collect it by a duo-bin $(9 \%)$ or a bag $(12 \%) .{ }^{11}$ For compostable also a bin of 120 or 240 litters is dominant with $90 \% .{ }^{12}$ Other containers for compostable waste are a duo-bin (9\%), a bag $(2 \%)$ or a crate $(1 \%)$. However, for paper a crate is dominant with $59 \% .{ }^{13}$ Other containers for papers are a mini-bin $(35 \%)$, a duo-bin $(1 \%)$ or a bag $(3 \%)$. For glass mini-bin $(1 \%)$ or a crate $(4 \%)$ is used. Most glass is collected by drop-off facilities. For textile a bag is dominant with $56 \% .{ }^{14}$ Other containers for textile are a mini-bin $(5 \%)$, a duo-bin or a crate $(10 \%)$. Finally, for plastics a bag is the most important with $30 \%$. Other containers for plastics are a mini-bin $(5 \%)$ or a crate $(3 \%)$.

\footnotetext{
${ }^{11}$ In some municipalities more than one system is used, resulting in a total share higher than $100 \%$.

12 Our dataset does not contain information on the size of the container.

${ }^{13}$ Our dataset does not contain information about the size of this crate. In some municipalities the size is $45 \times 28 \times 20 \mathrm{~cm}$ and these crates are distributed by the municipality. In some municipalities carton boxes (for example coming from sales in shops) are allowed to be used.

${ }^{14}$ In some municipalities these sacks are signed or have a special color.
} 


\section{Figure 4. The curbside frequency in number of pickups per year}

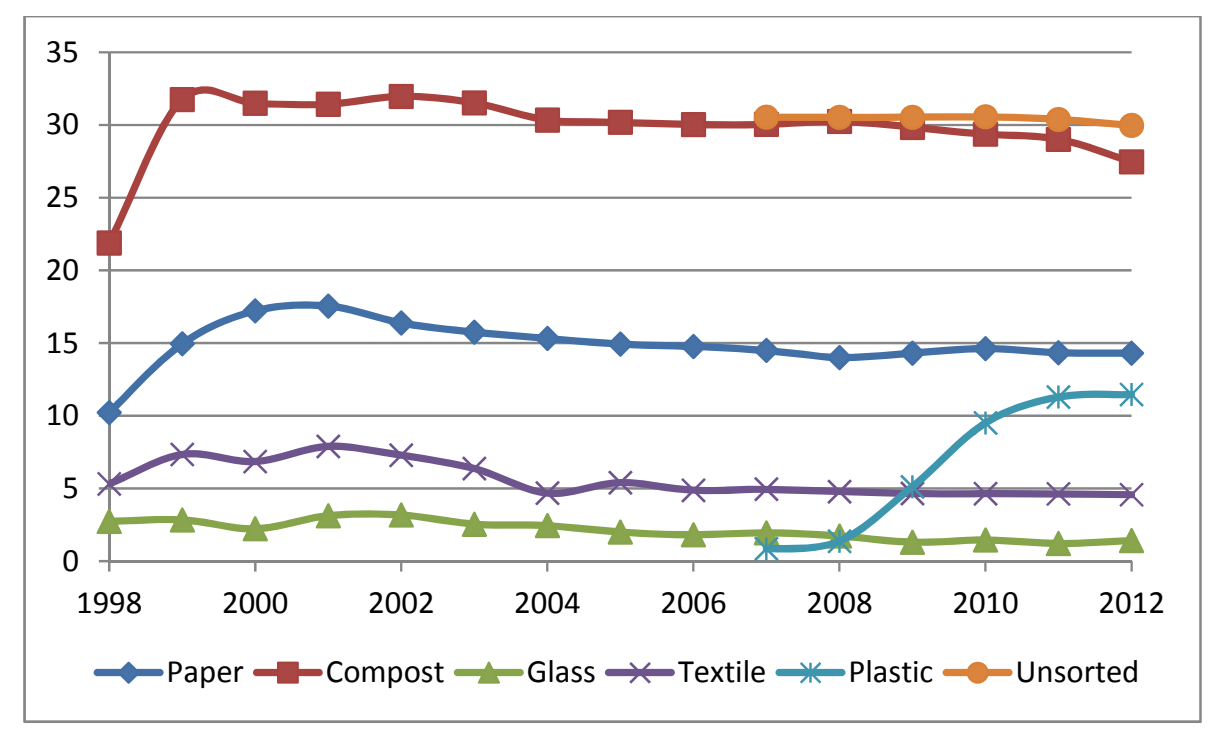

Note: for unsorted waste and plastics we have only data from 2007 on

The way citizens pay for waste collection differs per municipality. In most Dutch municipalities, ranging from $85 \%$ in 1998 to $63 \%$ in 2012, a flat-rate system has been used. In other municipalities unit-based pricing is used for unsorted and/or compostable waste. This introduces a price with the incentive to reduce the quantity of waste and to sort the waste better. Thus, with UBP it is expected that municipalities collect less priced waste and more unpriced recyclable waste. As in Dijkgraaf and Gradus (2004, 2014), we distinguish between four different unit-based pricing (UBP) systems: volume, frequency, bag and weight. The volume-based program allows households to choose between different volumes of collection bins for unsorted and/or compostable waste; on average between 1998 and 2012 7\% of Dutch municipalities used this rather crude UBP system. A more refined marginal price results from a frequency-based system, in which the household pays for the number of times the bin for unsorted and compostable waste is presented at the curbside. The share of municipalities using this system increased from 4\% in 1998 to 19\% in 2012 (on average 13\%) and in Dijkgraaf and Gradus (2014a) we argue that this is due to the low administrative costs. In the bag-based system, households buy a special bag with specific marks for unsorted waste. This is a more refined pricing system than the frequency-based one, as the volume of the bags is significantly less than that of the bins. Importantly, the bag system allows households to change volume each week. The share of municipalities with such a system is stable, at $4 \%$ in 1998 and 2012 and for most municipalities this bag is only used for unsorted waste. Maximum price incentives result from a weight-based system, pricing the unsorted and 
compostable waste per kilogram. The collection vehicle weighs the bin before emptying and combines this information with the identity of the owner, stored in a chip integrated in the collection bin. The more refined weight-based system increased at the beginning of this century and due to large administrative costs stabilized after 2005 with 5\%.

\section{Results}

We follow Kinnaman and Fullerton (2000) and estimate the material-specific recycling rates as a series of demand equations. Since the independent variables in each equation are the same, there is no bias from estimating the system as separate equations. First, we estimate equation (1) for the full sample and therefore we have to omit container type and the frequency for unsorted waste and plastics. Second, for the period 2007-2012 we can estimate all coefficients of equation (1). Table 2 and 3 shows the estimation results for the recycling rate functions (with for Table 3 also the plastic recycling rate). All estimations are based on pooled data with the robust cluster variance estimator with the municipality as the cluster indicator (see footnote 6).

Table 2. Estimation results share in total waste (1998-2012)

\begin{tabular}{llllll}
\hline & Unsorted (\%) & Paper (\%) & Compost (\%) & Glass (\%) & Textile (\%) \\
\hline Household size & -0.0152 & 0.0025 & $0.0770^{*}$ & -0.0122 & $-0.0153^{* * *}$ \\
Population density & -0.0149 & 0.0020 & 0.0143 & -0.0043 & 0.0018 \\
Foreigners/inhabitant & $0.0134^{* *}$ & -0.0002 & $-0.0112^{*}$ & 0.0003 & -0.0007 \\
Income/inhabitant & -0.0172 & 0.0074 & 0.0062 & 0.0053 & $0.0044^{*}$ \\
UBP: volume & $-0.0223^{* * *}$ & $0.0105^{* * *}$ & $0.0104^{* *}$ & 0.0018 & 0.0001 \\
UBP: frequency & $-0.0242^{* * *}$ & $0.0493^{* * *}$ & $-0.0531^{* * *}$ & $0.0164^{* * *}$ & $0.0023^{* * *}$ \\
UBP: bag & $-0.1431^{* * *}$ & $0.0319^{* * *}$ & $0.0836^{* * *}$ & $0.0139^{* * *}$ & 0.0030 \\
UBP: weight & $-0.0501^{* * *}$ & $0.0985^{* * *}$ & $-0.1043^{* * *}$ & $0.0302^{* * *}$ & $0.0043^{* *}$ \\
Frequency: paper & $-0.0002^{*}$ & 0.0001 & 0.0001 & 0.0000 & 0.0000 \\
Frequency: compostable & $0.0004^{* * *}$ & 0.0000 & $-0.0004^{* * *}$ & 0.0000 & $0.0000^{* *}$ \\
Frequency: glass & $-0.0005^{* * *}$ & 0.0002 & 0.0000 & 0.0001 & 0.0000 \\
Frequency: textile & $-0.0001^{*}$ & 0.0000 & 0.0001 & 0.0000 & 0.0000 \\
Bring: paper & $-0.0026^{*}$ & $0.0018^{* *}$ & 0.0013 & 0.0000 & $-0.0003^{* *}$ \\
Bring: glass & $0.0116^{*}$ & -0.0054 & -0.0020 & -0.0002 & 0.0001 \\
Bring: textile & -0.0019 & $0.0022^{* *}$ & -0.0005 & -0.0003 & $0.0008^{* * *}$ \\
R & & & & & 0.09 \\
Observations & 0.54 & 0.56 & 0.44 & 5321 & 5321 \\
\hline Note: & 5321 & 5321 & 5321 & & 0.09 \\
\hline
\end{tabular}

Note: $* * * / * * / *$ indicates significance at $99 \% / 95 \% / 90 \%$. 
Table 3. Estimations share in total waste with type of container (2007-2012)

\begin{tabular}{|c|c|c|c|c|c|c|}
\hline & Unsorted (\%) & Paper $(\%)$ & Compost $(\%)$ & Glass (\%) & Textile $(\%)$ & Plastic (\%) \\
\hline Household size & -0.1011 & 0.0623 & $0.2574 * *$ & -0.0166 & -0.0008 & $-0.1232 * *$ \\
\hline Population density & -0.0060 & 0.0019 & 0.0074 & -0.0076 & $-0.0084 * *$ & 0.0140 \\
\hline Foreigners/inhabitant & $0.0190 *$ & -0.0087 & -0.0060 & $-0.0055 * *$ & -0.0001 & 0.0013 \\
\hline Income/inhabitant & -0.0264 & $-0.0801 * *$ & $0.0913 * *$ & -0.0018 & 0.0035 & $0.0410 *$ \\
\hline UBP: volume & $-0.0331 * * *$ & $0.0137 * * *$ & $0.0206 * * *$ & 0.0007 & 0.0000 & -0.0039 \\
\hline UBP: frequency & $-0.0383 * * *$ & $0.0453 * * *$ & $-0.0383 * * *$ & $0.0138 * * *$ & $0.0024 * *$ & $0.0200 * * *$ \\
\hline UBP: bag & $-0.2398 * *$ & $0.0967 * * *$ & 0.0705 & $0.0356 * * *$ & $0.0061 * * *$ & $0.0840 * * *$ \\
\hline UBP: weight & $-0.0783 * * *$ & $0.0996^{* * *}$ & $-0.0866^{* * *}$ & $0.0290 * * *$ & $0.0070 * * *$ & $0.0351 * * *$ \\
\hline Frequency: unsorted & $0.0004 * *$ & $0.0002 *$ & $-0.0007 * * *$ & 0.0000 & 0.0000 & 0.0001 \\
\hline Frequency: paper & -0.0001 & 0.0001 & 0.0001 & 0.0000 & 0.0000 & 0.0000 \\
\hline Frequency: compost & $0.0002 * *$ & 0.0000 & -0.0001 & 0.0000 & 0.0000 & 0.0000 \\
\hline Frequency: glass & 0.0000 & 0.0000 & -0.0002 & 0.0001 & 0.0000 & 0.0001 \\
\hline Frequency: textile & 0.0000 & 0.0000 & 0.0001 & $-0.0001^{*}$ & $0.0000^{*}$ & 0.0000 \\
\hline Frequency: plastic & 0.0000 & 0.0000 & -0.0001 & 0.0000 & 0.0000 & 0.0000 \\
\hline Bring: paper & -0.0010 & $0.0019 *$ & -0.0005 & -0.0002 & 0.0000 & 0.0004 \\
\hline Bring: glass & -0.0017 & 0.0019 & 0.0007 & -0.0008 & -0.0004 & -0.0027 \\
\hline Bring: textile & 0.0024 & 0.0016 & -0.0028 & $-0.0007^{*}$ & 0.0002 & -0.0008 \\
\hline Unsorted: duo-bin & $-0.0847 * *$ & $0.0169 *$ & $0.0415^{*}$ & $0.0119 * * *$ & $0.0039 * *$ & 0.0003 \\
\hline Unsorted: bag & -0.0079 & $-0.0100^{*}$ & $0.0156^{* * *}$ & $0.0018^{*}$ & -0.0002 & -0.0002 \\
\hline Compost: duo-bin & $0.1184 * * *$ & $-0.0206^{* *}$ & $-0.0707 * * *$ & $-0.0108 * *$ & $-0.0052 * * *$ & -0.0025 \\
\hline Compost: bag & -0.0117 & 0.0046 & 0.0026 & -0.0001 & -0.0001 & -0.0004 \\
\hline Compost: crate & 0.0073 & 0.0032 & -0.0034 & -0.0053 & 0.0003 & -0.0039 \\
\hline Paper: duo-bin & -0.0139 & 0.0039 & 0.0090 & 0.0009 & 0.0013 & -0.0081 \\
\hline Paper: bag & -0.0007 & -0.0028 & -0.0002 & -0.0004 & 0.0014 & -0.0004 \\
\hline Paper: crate & $0.0064 * *$ & -0.0026 & $-0.0046^{*}$ & 0.0003 & 0.0003 & -0.0001 \\
\hline Glass: duo-bin & -0.0008 & $0.0681 * * *$ & $-0.0506 * * *$ & $-0.0085 * * *$ & $0.0055 * * *$ & $0.0000 * * *$ \\
\hline Glass: crate & 0.0144 & -0.0080 & -0.0040 & 0.0012 & -0.0003 & $-0.0171 * *$ \\
\hline Textile: duo-bin & -0.0057 & $-0.0153^{*}$ & $0.0240 * * *$ & 0.0029 & -0.0007 & $0.0000 * * *$ \\
\hline Textile: bag & -0.0026 & -0.0004 & $0.0041 *$ & 0.0003 & 0.0000 & 0.0009 \\
\hline Textile: crate & -0.0008 & 0.0017 & -0.0016 & 0.0007 & 0.0000 & $0.0032 * *$ \\
\hline Plastic: duo-bin & 0.0224 & -0.0071 & -0.0194 & -0.0063 & 0.0000 & $0.0169 * * *$ \\
\hline Plastic: bag & $-0.0071 * * *$ & -0.0005 & -0.0009 & 0.0002 & 0.0004 & $0.0043 * * *$ \\
\hline Plastic: crate & -0.0006 & -0.0020 & 0.0021 & -0.0009 & 0.0001 & -0.0012 \\
\hline $\mathrm{R}^{2}$ & 0.52 & 0.60 & 0.39 & 0.43 & 0.04 & 0.23 \\
\hline Observations & 1972 & 1972 & 1972 & 1972 & 1972 & 1165 \\
\hline
\end{tabular}

Let us review the econometric results. In terms of the socio-economic variables we find that most variables have poor explanatory power. Only for 2007-2012 for paper and compostable waste the income coefficient is significant (at 95\%) and one time positive and one time negative. According to Abbott et al. (2011) two opposing effects are working here. Higher 
earners have a higher propensity to recycle because the environment is a luxury good but also have a higher opportunity cost of time which acts to reduce their recycling rates. For compostable waste, it is to be expected that higher income municipalities have more houses with bigger gardens and thus more compostable waste to recycle. Paper is far less income sensitive, making it explainable that the effect is different. Plastic and textile have a positive relation with income, resulting in significant higher recycling rates if income increases in some estimations. The estimated coefficient for population density is only significant and negative and for textile in the period 2007-2012. This result is similar to Callan and Thomas (1997) and Kinnaman and Fullerton (2000), who both found a significant and negative relationship between population density and recycling. In the composting equation the coefficient for household size is significant (in the full panel at $90 \%$ ) and positively signed. A reason for this result could be that larger households tend to live in larger properties e.g. detached housing with bigger garden space and hence more opportunity for composting. Interestingly, in the textile equation of the full panel the coefficient for household size is significant and negatively signed. A possible explanation for this is that larger households have more opportunity to transfer clothes in the same household. For plastic we also find a negative effect. It could be possible that larger family size results in higher opportunity costs of time due to increasing scarcity of time as more time is spend for the family. Based on our results, foreign people recycle less glass and compostable waste, although the last result is only significant at the $90 \%$-level. This is contraire to results by Abbott et al. $(2013,2014)$ as they suggest that especially ethnic foreigners have a better social norm to recycle. ${ }^{15}$

Our results for collection frequency are diverse, but in most cases we find an insignificant effect. Intuitively, we would expect a positive relationship between the frequency of collection and the quantity of collected waste. However, in most cases the frequency coefficients are very small and insignificant. Only for textile and unsorted waste in the 20072012 panel we find a positive and significant result (see Table 3). Surprisingly, if the compost collection frequency increases the consequence in the full panel is a (small) rise in the compost rate. Abbott et al. (2011) argue that the nature of the composting activity is such that it takes place on a much more infrequent basis and in general the collection will not match to

\footnotetext{
${ }^{15}$ Abbott et al. $(2013,2014)$ examine the role of social norms in general. Based on English local authority data they show that a social norm for recycling exists. In their empirical investigation the social norm is defined using (1) the age profile of the authority, (2) the ethnic profile; and (3) the educational attainment. In all three cases, the estimates for social norms are positively correlated with the recycling rate and the variable is shown to be statistically significant as well.
} 
the compost-production set out by the household. A negative effect could be possible if more often collection is combined with smaller bins making the match even worse. However, as we have no data on the size of bins, we leave this for further research.

For the cross effects we find in nearly all cases an insignificant coefficient. For the full panel four cross-effects are significant. But even in this case coefficients are very small. Interestingly, and also in line with Abbott et al. (2011) we find that a decrease in the frequency of unsorted waste collection increases the recycling rate of compostable waste (see Table 3). The intuition behind this result is that when faced with fewer unsorted waste collections, households have an incentive to exert more effort in separating compostable waste from unsorted waste. By its nature, compostable waste is bulky and organic (leading to rotting and smells) and both stimulate the desirability of separate and outdoors storage.

The results for unit-based pricing systems are in line with the earlier literature for the Netherlands (e.g. Allers and Hoeben (2010), Dijkgraaf and Gradus (2004, 2014a)). ${ }^{16}$ Unitbased pricing systems are effective in reducing unsorted waste and stimulating recyclable waste. For the paper, glass, textile and plastic recycling rate nearly all UBP-coefficients are significant and positive. Especially, the bag-based system is effective in reducing the unsorted waste rate as from Table 2 it follows that the reduction is 14,3\% (and from Table 3 the reduction is even larger with $24,0 \%{ }^{17}$ ). However, disadvantages of the bag-based system are that Dutch legislation limits the number of bags carried per waste collection employee and that there is an incentive for households to put as much waste as possible in each bag, which makes them difficult to handle. ${ }^{18}$ Furthermore, it should be noticed that a policy of introducing a bag is contrary to the frequency and weight system as they stimulate home composting ${ }^{19}$. Interestingly, home composting lowers the (measured) recycling rate as it is not included in the official statistics. For the weight-based and frequency-based pricing system the disadvantages of the bag system are not taking place and in most cases there are sizeable

\footnotetext{
${ }^{16}$ In Dijkgraaf and Gradus (2004) and Allers and Hoeben (2010) the effect of unit-based pricing on total waste, unsorted waste, (total) recyclable waste and compostable waste is estimated. In Dijkgraaf and Gradus (2014a), the effect of unit-based pricing on costs is estimated.

${ }^{17}$ An explanation for this is that nowadays the bag-based system is generally used for unsorted waste only. Also Allers and Hoeben (2010) shows that the number of municipalities pricing compostable waste dropped markedly between 1997 and 2006. This point is also illustrated by Table 3, which shows that by using the bag-based system there is a (non-significant) increase in compostable waste.

${ }^{18}$ For some (coastal) municipalities there are some indications that bags have another disadvantage as births (like gulls) will give extra nuisance.

${ }^{19}$ In the Netherlands some municipalities stimulates home composting by subsidizing the purchase of home composting containers (see Linderhof et al. (2001)).
} 
reductions in unsorted waste rate, although for these policies effects are not larger than $10 \%$. The introduction of these unit-based pricing systems may, however, have adverse effects as well. Especially, the weight-system has large administrative costs and citizens may dump their waste illegally. However, Dijkgraaf and Gradus (2004) and Allers and Hoeben (2010) show that there is no evidence that surrounding municipalities without unit-based pricing systems in fact collect part of the waste produced in Dutch municipalities with unit-based pricing systems. In other studies there is some evidence that illegal dumping is an important issue. Fullerton and Kinnaman (1996) estimate that for a unit-based pricing system in Charlottesville (Virginia, US), illegal dumping constitutes $28 \%$ of the total reduction in waste collected at the curb.

For the full panel, in municipalities with curbside collection and extra bring locations for paper and textile we find more recyclables and less unsorted waste. However, for glass the coefficient is insignificant. It should be noticed that some glass in the Netherlands is recycled by the producer as a result of the packaging deposit money system for beer bottles. For 20072012 when the full equation is estimated we find no effects at $95 \%$. Only for paper we find a positive effect at $90 \%$. Therefore, we can conclude that the evidence for bring locations is mixed. ${ }^{20}$

We also get some interesting results for the type of container. It shows that most effects are found for the duo-bin. ${ }^{21}$ The effect of the duo-bin is $3.4 \%$ more unsorted waste and $2.9 \%$ less compostable waste (compared with the benchmark, a normal bin). Also for paper and textile the effects are negative and therefore from a recycling point of view we should omit a duo-bin for these substances. The exception is plastic, where we find a small positive effect.

For the other collection types only for bags a significant (and positive) effect is found on the own recycling rates. However, the effect is very small. Some collection types have crosseffects. Collecting unsorted waste by bags increases the quantity of waste collected for compost and glass. This is explainable, as putting compostable waste in bags increases the risk of smells and putting glass in bags increases the risk of bag bursting.

\footnotetext{
${ }^{20}$ Of course, these conclusion also depends on the way these bring locations are exactly located, but we have no information on this.

${ }^{21}$ Most duo-bins are used for simultaneously for unsorted and compostable waste. In appendix $b$ we present the correlation coefficients for the independent variables. As observed in this appendix there is almost a perfect correlation (i.e. 0.98) between a duo-bin for unsorted waste and for compostable waste. Therefore, the effect of a duo-bin is the combination of both coefficients (for duo-bin unsorted and compostable waste) in Table 3.
} 


\section{Cost functions}

Similar to equation (1), we model municipal waste costs as a function of output (i.e. the number of households $(\mathrm{HH})$ ), socio-economic variables, unit-based pricing dummies, curbside frequency variables, dummies for nearby collection points and container types as follows:

$$
\begin{aligned}
& \ln C_{i t}=\alpha_{0}+\beta_{0} \ln (H H)_{i t}+\beta_{1} \ln (H Z)_{i t}+\beta_{2} \ln (P D)_{i t}+\beta_{3} \ln (F O)_{i t}+\beta_{4} \ln (Y)_{i t}+ \\
& \sum_{j=1}^{n} \gamma_{j} U B P_{j i t}+\sum_{k=1}^{m} \theta_{k} F R_{k i t}+\sum_{k=1}^{m^{\prime}} \delta_{k} B R_{k i t}+\sum_{\substack{1 \leq k \leq m \\
1 \leq s \leq d}} \varnothing(k, s) C R_{s k i t}+\alpha_{0}+ \\
& \varepsilon_{i t}
\end{aligned}
$$

In equation (2) $\mathrm{C}_{\mathrm{it}}$ are the (total) real waste costs in municipality $\mathrm{i}$ at time period $\mathrm{t}$ and $\mathrm{HH}_{\mathrm{it}}$ is the number of households in municipality $i$ at time period $t$. It is quite common to include such an output factor in these cost functions to correct for scale effects (see Callan and Thomas (2001), Dijkgraaf and Gradus (2013, 2014a)). The estimations are given in Table 4. Let us first discuss the unit-based pricing effects. The results with respect to the unit-based pricing systems for the full panel are comparable with Dijkgraaf and Gradus (2014a). The cost advantage of introducing a system based on the volume of the collection is smallest, at $4.4 \% .^{22}$ The UBP system based on frequency reduces the total costs by $9.6 \%$. Notice that, based on cost reduction, the bag-based system is preferred to the weight-based system. The cost reduction is much smaller $(7.8 \%)$ for the weight-based system than for the bag-based system (12.8\%), as administrative costs are much higher for the weight system and the bag system reduces unsorted waste more. The estimate for the output factor, which is the number of households, indicates constant returns to scale as the coefficient is very close to 1 .

Some different results are found if we limit the panel to the period 2007-2012 (see second column Table 4). The cost advantage for unit-based pricing systems disappears. For the volume-based and the bag-based frequency system the advantage even become a disadvantage. For the frequency-based and weight-based the cost-advantage effect is smaller and insignificant. Based on robustness tests it can be shown that this is due to technical reasons. If we exclude fixed effects and we compare the UBP effects for the full panel and

\footnotetext{
${ }^{22}$ As the dependent variable is in logs, the effects of the UBP dummies are calculated using $\mathrm{e}^{\mathrm{x}}-1$, where $\mathrm{x}$ is the estimated coefficient.
} 
Table 4. Estimations share in total waste with type of container (2007-2012)

\begin{tabular}{|c|c|c|}
\hline & $1998-2012$ & 2007-2012 \\
\hline Households & $0.9923 * * *$ & $1.0757 * * *$ \\
\hline Household size & $0.4275^{* *}$ & $1.2775^{* * *}$ \\
\hline Population density & -0.0352 & -0.1264 \\
\hline Foreigners/inhabitant & -0.0078 & -0.0045 \\
\hline Income/inhabitant & $0.1937 * *$ & -0.0999 \\
\hline UBP: volume & $-0.0445^{* * *}$ & 0.0183 \\
\hline UBP: frequency & $-0.1010 * * *$ & -0.0381 \\
\hline UBP: bag & $-0.1380 * *$ & $0.0697 * *$ \\
\hline UBP: weight & $-0.0812 * *$ & -0.0506 \\
\hline Frequency: unsorted & - & $0.0010^{* * *}$ \\
\hline Frequency: paper & -0.0001 & -0.0003 \\
\hline Frequency: compost & 0.0000 & -0.0002 \\
\hline Frequency: glass & -0.0002 & -0.0003 \\
\hline Frequency: textile & -0.0002 & 0.0001 \\
\hline Frequency: plastic & - & -0.0002 \\
\hline Bring: paper & 0.0015 & 0.0007 \\
\hline Bring: glass & 0.0027 & 0.0062 \\
\hline Bring: textile & -0.0041 & 0.0019 \\
\hline Unsorted: duo-bin & - & 0.0548 \\
\hline Unsorted: bag & - & -0.0129 \\
\hline Unsorted: crate & - & -0.0448 \\
\hline Compost: duo-bin & - & -0.0685 \\
\hline Compost: bag & - & -0.0314 \\
\hline Compost: crate & - & 0.0101 \\
\hline Paper: duo-bin & - & -0.0386 \\
\hline Paper: bag & - & -0.0052 \\
\hline Paper: crate & - & 0.0097 \\
\hline Glass: duo-bin & - & 0.0019 \\
\hline Glass: crate & - & -0.0397 \\
\hline Textile: duo-bin & - & -0.0072 \\
\hline Textile: bag & - & -0.0096 \\
\hline Textile: crate & - & 0.0099 \\
\hline Plastic: duo-bin & - & -0.0257 \\
\hline Plastic: sack & - & 0.0049 \\
\hline Plastic: crate & - & -0.0018 \\
\hline $\mathrm{R}^{2}$ & 0.97 & 0.95 \\
\hline Observations & 6300 & 2362 \\
\hline
\end{tabular}


2007-2012 panel the differences are very small. ${ }^{23}$ Evidently, with the small 2007-2012 panel, the fixed effects absorbe to much variance in the data. Therefore, we conclude that the UBP costs effects can be represented by the first column of Table 4. We still present these results as we have only data for collection type and the frequency of collection for unsorted and plastic waste for the 2007-2012 panel. Robustness tests show that the results for these variables do not change significantly if we exclude fixed-effects. ${ }^{24}$

It should be noticed that none of the container variables is significant in the cost estimation. So, choices should be based on quantitative effects on waste collection. For most frequency variables the effect is small and insignificant. However, costs will increase if the frequency of residual waste increases. This is due to two elements: more substitution between unsorted waste and compostable waste and higher transportation costs.

\section{Conclusions}

In the Netherlands there is a long history of policies to stimulate household recycling of waste. On average, Dutch municipalities recycle approximately $50 \%$ and only a small number of municipalities recycle more than $70 \%$, the goal which has been announced by the European Union. By using panel data for 1998-2012 we explain recycling rates for household waste. We explore which policies are effective in increasing the recycling rates of different materials as paper, glass, textiles and from 2007 on also plastic packaging. Our main conclusion is that it is hard to achieve this goal as not many policies have a significant and large effect on the recycling rates.

In line with earlier contributions (e.g. Dijkgraaf and Gradus (2004, 2014a)), we show that unit-based pricing systems such as the weight- and bag-based systems are very effective as the reductions in unsorted waste are sizeable and recyclables increase substantially. However, even for these policies effects are not larger than $10 \%$, while most effects are only a few percents. Furthermore, these systems can have some adverse effects such as administrative costs and risks of illegal dumping. The bag-based system can be more effective in reducing unsorted waste but it has additional adverse effects on other policies such as home composting and there are problems with carrying these bags, smells and bag bursting. Interestingly, we show that avoiding a duo-bin for unsorted and compostable waste decreases

${ }^{23}$ These results are available on request.

${ }^{24}$ Also these results are available on request. 
the unsorted waste rate with more than $3 \%$. In addition, also avoiding a crate for paper and introducing a bag for plastics is effective in reducing the unsorted waste rate, although the effects are substantially smaller. Overall only bag-based pricing results in substantially higher recycling rates, which makes the goal of $70 \%$ in the EU for many municipalities out of reach.

Other important explanations for the (recycling) rate are social norms and socio-economic circumstances (see also Abbott et al. $(2013,2014)$ ). We show that especially the share of nonwestern foreigners is important in explaining the unsorted waste rate and household size plays an important role in explaining the recycling rate of compostable and textile. Based on these estimations it can be argumented that larger cities with many foreigners, a small household size and less possibilities for composting will not achieve such a goal. By estimating a cost function we show that moving back the frequency of unsorted waste and applying unit-based pricing lowers costs. Changing other types of frequency and the type of container has no influence on total collection cost.

There are many avenues to explore in future research. First, further explaining Dutch recycling rates can be of interest. In the literature, it is shown that especially educational attainment and age profile of citizens in a municipality are important in explaining these rates (see Abbott et al. (2013))). Second, it is important to have more data available especially for container type, plastics and the frequency of collecting unsorted waste. Currently, we have panel data for six years but as the unit-based pricing results show the results can be sensitive for including a fixed effect for municipality. Third, a municipal decisions can be influenced by a neighboring municipality for example if collection is combined or if external effects are present (like illegal dumping in other municipalities), and this can be tested using spatial models (see Brueckner (2003)). Fourth, also estimating the social costs functions of different recycling options can be of interest. Recently, Kinnaman et al. (2014) shows that average social costs are minimized with recycling rates well below mandated levels in Japan. Based upon the results of that paper, it appears that the $20 \%$ recycling rate in Japan is higher than the socially optimal rate $(10 \%)$. There is some evidence that this is also the case for Europe as well (see Dijkgraaf and Gradus (2014c)).

\section{References}

Abbot, A., S. Nandeibam, L. O'Shea (2011). 'Explaining the variation in household recycling rates across the UK', Ecological Economics, 70, 2214-23. 
Abbot, A., S. Nandeibam, L. O’Shea (2013). 'Recycling: Social norms and warm-glow revisited', Ecological Economics, 90, 10-18.

Abbot, A., S. Nandeibam, L. O’Shea (2014). 'Is there a social norm to recycle?', in: T. Kinnaman and K. Takeuchi (eds.) Handbook on Waste Management, Cheltenham (UK): Edward Elgar Publishers, pp. 53-74.

Allers, M. and C. Hoeben (2010) Effects of unit-based garbage pricing: a differences-indifferences approach. Environmental and Resource Economics 45(3): 405-28.

Beatty, T., P. Berck and J.P. Shimshack (2007), 'Curbside recycling in the presence of alternatives', Economic Inquiry 45(4): 739-55.

Brueckner, J. (2003) Strategic interaction among governments: an overview of empirical studies. International Regional and Urban Economics 26(2): 175-88.

Callan, S.J. and J.M. Thomas (1997): The impact of state and local policies on the recycling effort. Eastern Economic Journal 23(4): 411-423.

Callan, S.J. and J.M. Thomas (2001): Economics of Scale and Scope: A Cost Analysis of Municipal Solid Waste Services. Land Economics 77(4): 548-560.

Dijkgraaf, E. (2004), 'Regulating the Dutch waste market', PhD thesis, EUR, Rotterdam.

Dijkgraaf, E. and R.H.J.M. Gradus (2004), 'Cost savings in unit- based pricing of household waste: the case of the Netherlands', Resource and Energy Economics 26(4): 353-71.

Dijkgraaf, E. and R.H.J.M. Gradus (2009), 'Dynamics of unit-based pricing systems and environmental activism', Resource and Energy Economics 31(1): 13-23.

Dijkgraaf, E. and R.H.J.M. Gradus (2013), 'Cost advantage cooperations larger than private waste collectors', Applied Economics Letters 20(4): 702-5.

Dijkgraaf, E. and R.H.J.M. Gradus (2014a), 'Efficiency Effects of Unit-Based Pricing Systems and Institutional Choices of Waste Collection', forthcoming in Environmental and Resource Economics.

Dijkgraaf, E. and R.H.J.M. Gradus (2014b) Waste management in the Netherlands, in: T. Kinnaman and K. Takeuchi (eds.) Handbook on Waste Management, Cheltenham (UK): Edward Elgar Publishers, pp. 287-315.

Dijkgraaf E. and R.H.J.M. Gradus (2014c), "Europese recyclingdoelstelling: kleine milieuwinst tegen hoge kosten", Me Judice, 18 juli 2014 [in Dutch].

Euroactiv (2014). EU touts 70\% recycling and zero landfill law for 2030. www.euractiv.com [assessed 6 June 2014]

Ferrera, I. and P. Missios (2005), 'Recycling and Waste Diversion Effectiveness: Evidence from Canada', Environmental and Resource Economics 30(2): 221-238. 
Fullerton, D. and T.C. Kinnaman (1996), 'Household responses to pricing garbage by the bag', American Economic Review 86, 971-84.

Kinnaman, T.C., T. Shinkuma and M. Yamamoto (20014). The socially optimal recycling rate: Evidence from Japan. Journal of Environmental Economics and Management 68: 5470.

Kinnaman, T.C. and D. Fullerton (2000). Garbage and Recycling with Endogenous Local Policy. Journal of Urban Economics 48(3): 419-442

Kipperberg (2007). A Comparison of Household Recycling Behaviors in Norway and the United States, Environmental and Resource Economics 36(2): 215-235.

Linderhof, V., P. Kooreman, M. Allers and D. Wiersma (2001), 'Weight-based pricing in the collection of household waste: the Oostzaan case', Resource and Energy Economics 23, $359-71$.

Nichols, A. and M. Schaffer (2007) Clustered Errors in Stata. http://www.stata.com/meeting/13uk/nichols_crse.pdf.

Reus, P. and N. Jonkergouw (2013) Verkenning inzamelsystemen en inzamelpilots, SRE Milieudienst [in Dutch].

Usui, T. (2008). Estimating the effect of unit-based pricing in the presence of sample selection bias under Japanse Recycling Law. Ecological Economics 66: 282-288. 


\section{Appendix A. Definition of variables}

\begin{tabular}{|c|c|}
\hline Unsorted waste as $\%$ total collected waste & $\begin{array}{l}\text { Collected unsorted waste per inhabitant as percentage of total collected } \\
\text { waste per inhabitant }\end{array}$ \\
\hline Compostable waste as $\%$ total collected waste & $\begin{array}{l}\text { Separately collected compostable waste per inhabitant as percentage of } \\
\text { total collected waste per inhabitant }\end{array}$ \\
\hline Paper waste as $\%$ total collected waste & $\begin{array}{l}\text { Separately collected paper waste per inhabitant as percentage of total } \\
\text { collected waste per inhabitant }\end{array}$ \\
\hline Glass waste as $\%$ total collected waste & $\begin{array}{l}\text { Separately collected glass waste per inhabitant as percentage of total } \\
\text { collected waste per inhabitant }\end{array}$ \\
\hline Textile waste as $\%$ total collected waste & $\begin{array}{l}\text { Separately collected textile waste per inhabitant as percentage of total } \\
\text { collected waste per inhabitant }\end{array}$ \\
\hline Plastic waste as $\%$ total collected waste & $\begin{array}{l}\text { Separately collected plastic waste per inhabitant as percentage of total } \\
\text { collected waste per inhabitant }\end{array}$ \\
\hline Costs municipality (mln euro) & Total waste collection costs per municipality in million euro \\
\hline Household size & Number of inhabitants per household \\
\hline Population density & Municipal area in square meters per household \\
\hline Foreigners/inhabitant & Share of non-western foreigners in total number of inhabitants \\
\hline Income/inhabitant (thousand euro) & Income per inhabitant in thousand euro \\
\hline UBP: Volume & Dummy is 1 if volume-based pricing system is present and 0 otherwise \\
\hline UBP: Frequency & Dummy is 1 if frequency-based pricing system is present and 0 otherwise \\
\hline UPB: Bag & Dummy is 1 if bag-based pricing system is present and 0 otherwise \\
\hline UBP: Weight & Dummy is 1 if weight-based pricing system is present and 0 otherwise \\
\hline Bring: Paper & $\begin{array}{l}\text { Dummy is } 1 \text { if municipality has curbside collection of paper and a bring } \\
\text { system. }\end{array}$ \\
\hline Bring: Glass & $\begin{array}{l}\text { Dummy is } 1 \text { if municipality has curbside collection of glass and a bring } \\
\text { system. }\end{array}$ \\
\hline Bring: Textile & $\begin{array}{l}\text { Dummy is } 1 \text { if municipality has curbside collection of textile and a bring } \\
\text { system. }\end{array}$ \\
\hline Frequency: Unsorted & Number of times a year unsorted waste is collected at the curbside \\
\hline Frequency: Compost & Number of times a year compostable waste is collected at the curbside \\
\hline Frequency: Paper & Number of times a year paper waste is collected at the curbside \\
\hline Frequency: Glass & Number of times a year glass waste is collected at the curbside \\
\hline Frequency: Textile & Number of times a year textile waste is collected at the curbside \\
\hline Frequency: Plastic & Number of times a year plastic waste is collected at the curbside \\
\hline Unsorted: duo-bin & Dummy is 1 if unsorted waste is collected at the curbside by a duo-bin \\
\hline Unsorted: mini-bin & Dummy is 1 if unsorted waste is collected at the curbside by a mini-bin \\
\hline Unsorted: bag & Dummy is 1 if unsorted waste is collected at the curbside by a bag \\
\hline Unsorted: crate & Dummy is 1 if unsorted waste is collected at the curbside by a crate \\
\hline Compostable: duo-bin & $\begin{array}{l}\text { Dummy is } 1 \text { if compostable waste is collected at the curbside by a duo- } \\
\text { bin }\end{array}$ \\
\hline Compostable: mini-bin & $\begin{array}{l}\text { Dummy is } 1 \text { if compostable waste is collected at the curbside by a mini- } \\
\text { bin }\end{array}$ \\
\hline Compostable: bag & Dummy is 1 if compostable waste is collected at the curbside by a bag \\
\hline Compostable: crate & Dummy is 1 if compostable waste is collected at the curbside by a crate \\
\hline Paper: duo-bin & Dummy is 1 if paper waste is collected at the curbside by a duo-bin \\
\hline Paper: mini-bin & Dummy is 1 if paper waste is collected at the curbside by a mini-bin \\
\hline Paper: bag & Dummy is 1 if paper waste is collected at the curbside by a bag \\
\hline Paper: crate & Dummy is 1 if paper waste is collected at the curbside by a crate \\
\hline Glass: duo-bin & Dummy is 1 if glass waste is collected at the curbside by a duo-bin \\
\hline Glass: mini-bin & Dummy is 1 if glass waste is collected at the curbside by a mini-bin \\
\hline Glass: bag & Dummy is 1 if glass waste is collected at the curbside by a bag \\
\hline Glass: crate & Dummy is 1 if glass waste is collected at the curbside by a crate \\
\hline Textile: duo-bin & Dummy is 1 if textile waste is collected at the curbside by a duo-bin \\
\hline Textile: mini-bin & Dummy is 1 if textile waste is collected at the curbside by a mini-bin \\
\hline Textile: bag & Dummy is 1 if textile waste is collected at the curbside by a bag \\
\hline
\end{tabular}


Textile: crate

Plastic: duo-bin

Plastic: mini-bin

Plastic: bag

Plastic: crate
Dummy is 1 if textile waste is collected at the curbside by a crate

Dummy is 1 if plastic waste is collected at the curbside by a duo-bin

Dummy is 1 if plastic waste is collected at the curbside by a mini-bin

Dummy is 1 if plastic waste is collected at the curbside by a bag

Dummy is 1 if plastic waste is collected at the curbside by a crate 
Appendix B: Correlation- coefficients of exogenous variables

\begin{tabular}{|c|c|c|c|c|c|c|c|c|c|c|c|c|}
\hline & $\begin{array}{r}\text { Frequency: } \\
\text { unsorted } \\
\end{array}$ & $\begin{array}{r}\text { Frequency: } \\
\text { paper }\end{array}$ & $\begin{array}{r}\text { Frequency: } \\
\text { compost }\end{array}$ & $\begin{array}{r}\text { Frequency: } \\
\text { glass }\end{array}$ & $\begin{array}{r}\text { Frequency: } \\
\text { textile }\end{array}$ & $\begin{array}{r}\text { Frequency: } \\
\text { plastic }\end{array}$ & $\begin{array}{l}\text { Bring: } \\
\text { paper }\end{array}$ & $\begin{array}{l}\text { Bring: } \\
\text { glass }\end{array}$ & $\begin{array}{l}\text { Bring: } \\
\text { textile }\end{array}$ & $\begin{array}{r}\text { Unsorted: } \\
\text { duo-cont }\end{array}$ & $\begin{array}{r}\text { Unsorted: } \\
\text { bag } \\
\end{array}$ & $\begin{array}{r}\text { Unsorted: } \\
\text { crate } \\
\end{array}$ \\
\hline Frequency: unsorted & 1.00 & & & & & & & & & & & \\
\hline Frequency: paper & 0.05 & 1.00 & & & & & & & & & & \\
\hline Frequency: compost & 0.41 & 0.07 & 1.00 & & & & & & & & & \\
\hline Frequency: glass & 0.00 & 0.28 & 0.00 & 1.00 & & & & & & & & \\
\hline Frequency: textile & 0.01 & 0.25 & 0.04 & 0.60 & 1.00 & & & & & & & \\
\hline Frequency: plastic & 0.06 & 0.06 & 0.01 & 0.13 & 0.14 & 1.00 & & & & & & \\
\hline Bring: paper & 0.08 & 0.15 & 0.05 & -0.08 & 0.00 & 0.01 & 1.00 & & & & & \\
\hline Bring: glass & -0.04 & 0.18 & -0.03 & 0.77 & 0.43 & 0.03 & -0.04 & 1.00 & & & & \\
\hline Bring: textile & 0.05 & 0.04 & 0.06 & -0.02 & 0.25 & 0.12 & 0.20 & 0.06 & 1.00 & & & \\
\hline Unsorted: duo-bin & 0.41 & -0.01 & 0.51 & -0.03 & 0.00 & -0.02 & -0.02 & -0.02 & 0.01 & 1.00 & & \\
\hline Unsorted: bag & 0.51 & 0.02 & 0.12 & -0.04 & -0.01 & 0.06 & 0.13 & -0.06 & 0.05 & -0.07 & 1.00 & \\
\hline Unsorted: crate & 0.04 & 0.00 & 0.05 & 0.00 & 0.00 & -0.01 & 0.03 & 0.00 & -0.02 & -0.01 & 0.06 & 1.00 \\
\hline Compost: duo-bin & 0.42 & 0.00 & 0.52 & -0.03 & 0.00 & -0.03 & -0.03 & -0.02 & 0.01 & 0.98 & -0.07 & -0.01 \\
\hline Compost: bag & 0.19 & -0.01 & 0.28 & -0.02 & 0.01 & -0.01 & 0.06 & -0.01 & 0.01 & -0.04 & 0.33 & 0.14 \\
\hline Compost: crate & 0.01 & 0.01 & 0.14 & 0.04 & 0.06 & 0.05 & 0.01 & 0.05 & 0.04 & 0.03 & 0.07 & 0.21 \\
\hline Paper: duo-bin & 0.07 & -0.01 & 0.07 & -0.02 & 0.00 & 0.00 & 0.02 & -0.02 & 0.01 & 0.24 & -0.03 & 0.00 \\
\hline Paper: bag & -0.01 & 0.03 & 0.01 & 0.01 & 0.02 & -0.02 & 0.04 & 0.01 & 0.04 & 0.01 & 0.02 & 0.00 \\
\hline Paper: crate & 0.03 & 0.25 & 0.04 & 0.07 & 0.04 & 0.04 & 0.02 & 0.06 & 0.02 & 0.04 & 0.04 & 0.02 \\
\hline Glass: duo-bin & 0.02 & 0.00 & 0.00 & 0.12 & -0.01 & -0.01 & 0.00 & 0.06 & -0.02 & 0.03 & -0.01 & 0.00 \\
\hline Glass: crate & -0.02 & 0.20 & -0.01 & 0.65 & 0.35 & 0.03 & -0.03 & 0.72 & 0.02 & -0.03 & -0.04 & 0.00 \\
\hline Textile: duo-bin & -0.01 & -0.01 & -0.01 & 0.00 & 0.06 & -0.01 & -0.01 & 0.00 & 0.02 & 0.07 & -0.01 & 0.00 \\
\hline Textile: bag & 0.05 & 0.00 & 0.03 & -0.07 & 0.12 & 0.00 & 0.07 & -0.07 & 0.48 & 0.04 & 0.04 & 0.02 \\
\hline Textile: crate & 0.01 & 0.10 & 0.04 & 0.24 & 0.25 & -0.01 & 0.01 & 0.27 & 0.09 & -0.01 & 0.02 & -0.01 \\
\hline Plastic: duo-bin & 0.00 & 0.03 & 0.02 & -0.01 & -0.02 & 0.05 & -0.01 & -0.01 & -0.01 & 0.17 & -0.02 & 0.00 \\
\hline Plastic: bag & -0.02 & 0.00 & -0.07 & 0.01 & 0.00 & 0.51 & 0.02 & -0.04 & 0.08 & -0.07 & 0.01 & -0.01 \\
\hline Plastic: crate & -0.01 & 0.07 & 0.01 & 0.20 & 0.22 & -0.07 & -0.02 & 0.21 & 0.01 & 0.00 & -0.01 & 0.00 \\
\hline
\end{tabular}




\begin{tabular}{|c|c|c|c|c|c|c|c|c|c|c|c|c|c|c|}
\hline & $\begin{array}{r}\text { Compost: } \\
\text { duo-cont }\end{array}$ & $\begin{array}{r}\text { Compost: } \\
\text { bag }\end{array}$ & $\begin{array}{r}\text { Compost: } \\
\text { crate }\end{array}$ & $\begin{array}{r}\text { Paper: } \\
\text { duo-cont }\end{array}$ & $\begin{array}{r}\text { Paper: } \\
\text { bag }\end{array}$ & $\begin{array}{r}\text { Paper: } \\
\text { crate }\end{array}$ & $\begin{array}{r}\text { Glass: } \\
\text { duo-cont }\end{array}$ & $\begin{array}{r}\text { Glass: } \\
\text { crate }\end{array}$ & $\begin{array}{r}\text { Textile: } \\
\text { duo-cont }\end{array}$ & $\begin{array}{r}\text { Textile: } \\
\text { bag }\end{array}$ & $\begin{array}{r}\text { Textile: } \\
\text { crate }\end{array}$ & $\begin{array}{r}\text { Plastic: } \\
\text { duo-cont }\end{array}$ & $\begin{array}{r}\text { Plastic: } \\
\text { bag }\end{array}$ & $\begin{array}{r}\text { Plastic: } \\
\text { crate }\end{array}$ \\
\hline Compost: duo-cont & 1.00 & & & & & & & & & & & & & \\
\hline Compost: bag & -0.03 & 1.00 & & & & & & & & & & & & \\
\hline Compost: crate & 0.03 & 0.26 & 1.00 & & & & & & & & & & & \\
\hline Paper: duo-cont & 0.24 & -0.01 & -0.01 & 1.00 & & & & & & & & & & \\
\hline Paper: bag & 0.01 & 0.03 & 0.04 & -0.01 & 1.00 & & & & & & & & & \\
\hline Paper: crate & 0.03 & 0.05 & 0.05 & -0.07 & -0.17 & 1.00 & & & & & & & & \\
\hline Glass: duo-cont & 0.03 & -0.01 & 0.00 & 0.15 & -0.01 & -0.02 & 1.00 & & & & & & & \\
\hline Glass: crate & -0.03 & -0.03 & 0.00 & -0.02 & -0.03 & 0.09 & -0.01 & 1.00 & & & & & & \\
\hline Textile: duo-cont & 0.07 & 0.00 & 0.00 & 0.26 & 0.00 & -0.02 & 0.00 & 0.00 & 1.00 & & & & & \\
\hline Textile: bag & 0.04 & -0.05 & 0.03 & 0.00 & 0.08 & 0.07 & -0.04 & -0.11 & -0.02 & 1.00 & & & & \\
\hline Textile: crate & -0.01 & 0.13 & 0.00 & -0.03 & -0.03 & 0.14 & 0.03 & 0.35 & -0.01 & -0.33 & 1.00 & & & \\
\hline Plastic: duo-cont & 0.11 & -0.01 & -0.01 & 0.23 & 0.03 & -0.01 & 0.17 & -0.01 & 0.00 & 0.00 & -0.02 & 1.00 & & \\
\hline Plastic: bag & -0.07 & 0.00 & 0.05 & -0.02 & -0.01 & 0.07 & -0.02 & -0.01 & -0.01 & 0.04 & -0.01 & -0.04 & 1.00 & \\
\hline Plastic: crate & 0.00 & 0.05 & -0.02 & -0.01 & 0.02 & 0.04 & -0.01 & 0.21 & 0.00 & -0.06 & 0.27 & -0.01 & -0.10 & 1.00 \\
\hline
\end{tabular}

